\title{
Alternative substrates for production of yellow passion fruit seedlings
}

\author{
Eduardo Santana Aires ${ }^{1}$, Carlos Alberto Aragão², Itala Laiane Silva Gomes², Gilmário \\ Noberto de Souza ${ }^{2}$, Isa Gabriela Vieira de Andrade ${ }^{2}$ \\ ${ }^{1}$ Universidade Estadual Paulista, Campus de Botucatu, Botucatu, São Paulo, Brasil. E-mail: e.aires@unesp.br \\ ${ }^{2}$ Universidade do Estado da Bahia, Campus-III, Juazeiro, Bahia, Brasil. E-mail: carlosaragao@hotmail.com, \\ itala.gomes@hotmail.com, gilmario.souza.gs@gmail.com, isagva@hotmail.com
}

Received: 23/08/2019; Accepted: 04/01/2020.

\begin{abstract}
This study aimed to evaluate different substrates to produce yellow passion fruit seedlings. For this purpose, an experiment was carried out in a greenhouse, from April to June 2016. A completely randomized design with five replications, in a $6 \times 5$ factorial scheme was used. The first factor was the alternative substrates (poultry, cattle and equine manure, sugarcane and coconut bagasse, and Organomais compost). The second factor was the replacement levels to the commercial substrate of Plantmax ${ }^{\circledR}(100: 0,75: 25,50: 50,25: 75,0: 100)$. The seedling evaluation was carried out 42 days after sowing. The following variables were analyzed: length, width, and the number of leaves; plant height and shoot dry matter. A significant effect $(\mathrm{P}<0.05)$ for the interaction between the factors was verified. The addition of $60 \%$ cattle manure and Organomais to the commercial substrate Plantmax ${ }^{\circledR}$ promoted greater length, width, and the number of leaves, plant height, and shoot dry matter accumulation in the yellow passion fruit seedlings.
\end{abstract}

Keywords: initial plant growth, organic matter, Passiflora edulis Sims f. flavicarpa Deg.

\section{Substratos alternativos para produção de mudas de maracujazeiro-amarelo}

\section{RESUMO}

Objetivou-se avaliar diferentes substratos na produção de mudas de maracujazeiro, para tanto, instalou-se em casa de vegetação experimento, no período de abril a junho de 2016, em delineamento inteiramente casualizado, em esquema fatorial duplo $6 \times 5$, onde o primeiro fator é composto por substratos alternativos (esterco de aviário, bovino e equino, bagaço de cana-de-açúcar, coco e composto Organomais) e o segundo fator são níveis de reposição ao substrato comercial de Plantamax ${ }^{\circledR}(100: 0,75: 25,50: 50,25: 75,0: 100)$, com cinco repetições. A avaliação das mudas foi realizada 42 dias após a semeadura, sendo analisadas as seguintes variáveis: comprimento, largura e número de folhas; altura da planta e peso de matéria seca da parte aérea. Através da análise de variâncias, verificouse efeito significativo $(\mathrm{P}<0,05)$ para a interação entre os fatores. A adição de $60 \%$ de esterco bovino e Organomais ao substrato comercial Plantmax ${ }^{\circledR}$ promoveu maior comprimento, largura e número de folhas, altura da planta, e maior acúmulo de matéria seca de mudas de maracujazeiro.

Palavras-chave: crescimento inicial de plantas, matéria orgânica, Passiflora edulis Sims f. flavicarpa Deg. 


\section{Introduction}

In 2017, Brazil produced around 700 thousand tons of passion fruit (Agrianual, 2018), which is the world's largest producer of passion fruit. However, according to Aguiar et al. (2015), the Brazilian producers have a low average yield of passion fruit due to technical problems during the production process and the management that is not always suitable for the crop, which results in increased production costs.

Generally, commercial substrates are used in the seedlings production of passion fruit, making this process more expensive and reducing the competitiveness of small producers. Alternatively, several materials can be used as a substrate to produce fruit seedlings. Some studies indicate sand, vermiculite, compost from urban garbage, manure, sugarcane bagasse, peanut husks, carbonized rice husks, pine husks, coconut bagasse, sawdust, among others as an alternative material for substrate (Lima et al., 2016; Brugnara et al., 2014; Oliveira et al., 2013).

Seedling production is an essential step in the production process of passion fruit. Santos et al. (2017b), studying the production and quality of yellow passion fruit from the seedlings of different ages, verified the use of seedlings aged from 100 to 125 days after emergence provided higher fruit production and quality.

In this way, the substrate used for seedling production should contain enough nutrients to supply your needs during this time, that is, the inert substrate only with the support function will become unsuitable for this type of management. Thus, the addition of alternative substrates, with low cost, accessible to producers, and that provide nutrients for the best growth and development of these plants can be an option to optimize this phase of the production process.

Given the above, this study aimed to evaluate the effect of different combinations of alternative substrates associated with a commercial substrate to produce yellow passion fruit seedlings.

\section{Material and Methods}

The experiment was carried out in a greenhouse with $50 \%$ shading, located in the Department of Technology and Social Sciences (DTCS), of the State University of Bahia, Campus III, Juazeiro-BA, from April to June 2016. The average annual temperature is $23.6^{\circ} \mathrm{C}$, relative humidity of $61.7 \%$, annual precipitation of $455 \mathrm{~mm}$, evaporation Class A tank of $1800 \mathrm{~mm}$, and average photoperiod of 11 hours/day (Table 1).

The seeds of yellow passion fruit (Passiflora edulis Sims f. flavicarpa Deg) were obtained through the selection of healthy fruits harvested in the production field, adopting physiological maturity and commercial quality criteria for their choice.

A completely randomized design with five replications, in a $6 \times 5$ factorial scheme was used. Six alternative substrates (poultry manure, cattle manure, equine manure; sugarcane bagasse; coconut bagasse, and Organomais compost) and five levels of substitution to the commercial substrate Plantmax ${ }^{\circledR}(100: 0 ; 75: 25$; $50: 50 ; 25: 75 ; 0: 100)$ were evaluated. The chemical properties of the substrates are shown in Table 2.

Table 1. Climatic conditions during the experimental period (From April to June 2016)

\begin{tabular}{cccc}
\hline & Average temperature $\left({ }^{\circ} \mathrm{C}\right)$ & Relative humidity (\%) & Solar radiation (ly.day) \\
\hline April & 27.1 & 67 & 505.5 \\
\hline May & 26.1 & 67 & 418.2 \\
\hline June & 24.2 & 69 & 389.2
\end{tabular}

Data collected from the Agrometeorological Station of Mandacaru, Juazeiro-BA. ly (langley) = calorie per square centimeter $\left(\mathrm{cal}_{\mathrm{cm}}^{-2}\right)$.

Table 2. Chemical properties of the substrates to produce yellow passion fruit seedlings, Juazeiro-BA (2016).

\begin{tabular}{|c|c|c|c|c|c|c|c|c|c|}
\hline \multirow{2}{*}{ Substrates } & $\mathrm{N}$ & $\mathrm{P}$ & $\mathrm{K}$ & $\mathrm{Ca}$ & $\mathrm{Mg}$ & $\mathrm{S}$ & $\mathrm{C} / \mathrm{N}$ & M.O & $\mathrm{pH}$ \\
\hline & \multicolumn{8}{|c|}{$\mathrm{g} \mathrm{kg}^{-1}$} & $\left(\mathrm{H}_{2} \mathrm{O}\right) 1: 2.5$ \\
\hline Plantmax $^{\circledR}$ & 4.90 & 1.47 & 7.00 & 12.50 & 120.0 & 2.80 & $34 / 1$ & 285.0 & 6.2 \\
\hline Poultry manure & 85.80 & 16.23 & 23.50 & 96.50 & 95.00 & 4.30 & $4 / 1$ & 630.0 & 8.2 \\
\hline Equine manure & 8.70 & 4.76 & 22.50 & 12.10 & 3.60 & 2.90 & $19 / 1$ & 280.0 & 9.5 \\
\hline Cattle manure & 14.50 & 1.77 & 15.50 & 120.00 & 100.50 & 4.50 & $25 / 1$ & 635.0 & 8.0 \\
\hline Sugarcane bagasse & 0.90 & 1.60 & 9.00 & 15.50 & 150.00 & 6.10 & $302 / 1$ & 470.0 & 5.5 \\
\hline Coconut bagasse & 5.20 & 0.88 & 16.00 & 9.30 & 2.00 & 3.50 & $8 / 1$ & 70.0 & 4.50 \\
\hline Organomais & 19.10 & 1.68 & 7.50 & 55.50 & 2.30 & 8.70 & $12 / 1$ & 390.0 & 6.90 \\
\hline
\end{tabular}


Before preparing the mixture, the substrates were sieved through a $4 \mathrm{~mm}$ sieve to uniformize the particle size $(<4 \mathrm{~mm})$. The volumetric proportions were prepared for each treatment: Plantmax ${ }^{\circledR}(100 \%)$; Plantmax ${ }^{\circledR}(75 \%)$ + Alternative substrate (25\%); Plantmax ${ }^{\circledR}(50 \%)+$ Alternative substrate $(50 \%)$; Plantmax $^{\circledR} \quad(25 \%)+$ Alternative substrate $(75 \%)$ and Alternative substrate (100\%).

The substrates were placed in a $290 \mathrm{~cm}^{3}$ container. Sowing was performed with two seeds per container. When the seedlings reached $3 \mathrm{~cm}$ height, thinning was made, leaving one plant per container. The irrigation was carried out with an automatic micro-sprinkler system, three times a day, to maintain the humidity of the substrates.

The seedlings were evaluated at 42 days after sowing (DAS). The leaf length and width, the number of leaves, and the plant height (with a graduate ruler) were evaluated. The plants were cut close to the ground and placed in a forced air circulation oven at $65^{\circ} \mathrm{C}$, for 72 hours to obtain the shoot dry matter.

The data were submitted to the analysis of variance $(\mathrm{P}<0.05)$. The Tukey test compared the means from the substrates at $5 \%$ probability. The means from the substitution levels of commercial substrate were adjusted by the regression analysis at $5 \%$ probability, according to the coefficient of determination. The best dose for each substrate was estimated from the regression equations.

\section{Results and Discussion}

There was found a significant effect $(\mathrm{P}<0.05)$ of the alternative substrates, of the substitution levels of commercial substrate, and the interaction between the factors on all variables. For leaf length (Table 3 ), it is observed that the highest results were obtained with cattle manure and Organomais compost, both with the best substitution level of the commercial substrate around $60 \%$ (X max).

The addition of doses higher than $50 \%$ of poultry manure caused the death of the plants. Therefore, excessive doses of this manure in the commercial substrate are not recommended. The excessive presence of this substrate with high $\mathrm{pH}$ and the high concentration of nitrogen, observed in Table 2, may have inhibited the absorption of nutrients, resulting in low growth or even in the death of the plants. Costa et al. (2015), studying different environments and substrates for tomato seedlings, also do not indicate doses higher than $50 \%$ of poultry manure for the formation of tomato seedlings. In this research, most of the plants did not develop or died due to the high substrate $\mathrm{pH}$.

Similar results to those observed for leaf length were verified for the leaf width (Table 4). Again, the alternative substrates with cattle manure and Organomais stand out as the best with the substitution level of the commercial substrate around $60 \%$. The superior behavior observed from the use of these substrates and the commercial substrate Plantmax $^{\circledR}$ is due to the combination of the proper physical properties of the substrate with the suitable chemical properties of the compound, making it a favorable structure for the development of seedlings. The association of organic materials, in mixture with soil, provides proper physical conditions, and provides the necessary nutrients for the growth of seedlings, corroborating the results obtained by Oliveira et al. (2015). They used doses of sheep manure to produce papaya seedlings. They found better responses for plant height and stem diameter when associating $60 \%$ of the manure to the commercial substrate, demonstrating that for the formation of seedlings, the substrate must also provide nutrients to obtain more vigorous plants.

Table 3. Leaf length of yellow passion fruit seedlings under different concentrations of alternative substrates, Juazeiro-BA (2016).

\begin{tabular}{|c|c|c|c|c|c|}
\hline \multirow{2}{*}{ Alternative Substrates } & \multicolumn{5}{|c|}{ Proportion of alternative substrate $(\%)$} \\
\hline & 0 & 25 & 50 & 75 & 100 \\
\hline & \multicolumn{5}{|c|}{ 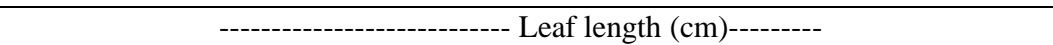 } \\
\hline Poultry manure & $1.69 \mathrm{a}$ & $8.14 \mathrm{ab}$ & $3.36 \mathrm{~b}$ & $0,00 \mathrm{c}$ & $0,00 \mathrm{e}$ \\
\hline Equine manure & $1.69 \mathrm{a}$ & $1.94 \mathrm{c}$ & $2.82 \mathrm{~b}$ & $3,56 \mathrm{~b}$ & $3,44 \mathrm{~cd}$ \\
\hline Cattle manure & $1.69 \mathrm{a}$ & $9.58 \mathrm{a}$ & $10.3 \mathrm{a}$ & 9,26 a & 7,68 a \\
\hline Sugarcane bagasse & $1.66 \mathrm{a}$ & $1.68 \mathrm{c}$ & $1.64 \mathrm{~b}$ & $1,54 \mathrm{c}$ & $1,64 \mathrm{de}$ \\
\hline Coconut bagasse & $1.68 \mathrm{a}$ & $2.26 \mathrm{c}$ & $2.68 \mathrm{~b}$ & $3,66 \mathrm{~b}$ & $4,3 \mathrm{bc}$ \\
\hline Organomais & $1.72 \mathrm{a}$ & $7.46 \mathrm{~b}$ & $9.84 \mathrm{a}$ & $9,70 \mathrm{a}$ & $5,80 \mathrm{~b}$ \\
\hline & \multicolumn{3}{|c|}{ Adjusted equations } & $\mathrm{R}^{2}$ & Xmax \\
\hline Poultry manure & \multicolumn{3}{|c|}{$\hat{\mathrm{Y}}=3.3073+0.08493 \mathrm{X}-0.001311 \mathrm{X}^{2}$} & 0.50 & 32.40 \\
\hline Equine manure & \multicolumn{3}{|c|}{$\hat{\mathrm{Y}}=1.6696+0.020432 \mathrm{X}$} & 0.90 & 100.00 \\
\hline Cattle manure & \multicolumn{3}{|c|}{$\hat{Y}=2.4113+0.2848 X-0.002383 X^{2}$} & 0.90 & 59.78 \\
\hline Sugarcane bagasse & \multicolumn{3}{|c|}{$\bar{Y}=1.63$} & --- & --- \\
\hline Coconut bagasse & \multicolumn{3}{|c|}{$\hat{Y}=1.588+0.02656 X$} & 0.99 & 100.00 \\
\hline Organomais & \multicolumn{3}{|c|}{$\hat{Y}=1.7097+0.2907 X-0.002491 X^{2}$} & 0.99 & 58.35 \\
\hline
\end{tabular}

The means followed by the same letter in the column do not differ statistically from each other by the Tukey test at $5 \%$ probability (P <0.05). Xmax - Best dose for the highest value of the studied variable. 
Table 4. Leaf width of yellow passion fruit seedlings under different concentrations of alternative substrates, Juazeiro-BA (2016).

\begin{tabular}{|c|c|c|c|c|c|}
\hline \multirow{2}{*}{ Alternative substrates } & \multicolumn{5}{|c|}{ Proportion of alternative substrate (\%) } \\
\hline & 0 & 25 & 50 & 75 & 100 \\
\hline & \multicolumn{5}{|c|}{---------------------- Leaf width $(\mathrm{cm})--------$} \\
\hline Poultry manure & $1.21 \mathrm{a}$ & $4.58 \mathrm{~b}$ & $1.86 \mathrm{~b}$ & $0,00 \mathrm{~d}$ & $0,00 \mathrm{~d}$ \\
\hline Equine manure & $1.21 \mathrm{a}$ & $1.38 \mathrm{c}$ & $1.60 \mathrm{~b}$ & $2,06 \mathrm{bc}$ & $2,06 \mathrm{bc}$ \\
\hline Cattle manure & $1.21 \mathrm{a}$ & $5.72 \mathrm{a}$ & $5.66 \mathrm{a}$ & $5,08 \mathrm{a}$ & $4,28 \mathrm{a}$ \\
\hline Sugarcane bagasse & $1.18 \mathrm{a}$ & $1.26 \mathrm{c}$ & $1.32 \mathrm{~b}$ & $1,32 \mathrm{bc}$ & $1,20 \mathrm{c}$ \\
\hline Coconut bagasse & $1.16 \mathrm{a}$ & $1.48 \mathrm{c}$ & $1.70 \mathrm{~b}$ & $2,38 \mathrm{~b}$ & $2,54 \mathrm{~b}$ \\
\hline \multirow[t]{2}{*}{ Organomais } & $1.24 \mathrm{a}$ & $3.90 \mathrm{~b}$ & $5.64 \mathrm{a}$ & $5,44 \mathrm{a}$ & $3,08 \mathrm{~b}$ \\
\hline & \multicolumn{3}{|c|}{ Adjusted equations } & $\mathrm{R}^{2}$ & $\mathrm{Xmax}$ \\
\hline Poultry manure & \multicolumn{3}{|c|}{$\hat{\mathrm{Y}}=2.09+0.0392 \mathrm{X}-0.000672 \mathrm{X}^{2}$} & 0.52 & 29.17 \\
\hline Equine manure & \multicolumn{3}{|c|}{$\hat{Y}=1.186+0.00952 X$} & 0.94 & 100.00 \\
\hline Cattle manure & \multicolumn{3}{|c|}{$\hat{Y}=1.6986+0.1493 X-0.001273 X^{2}$} & 0.85 & 58.64 \\
\hline Sugarcane bagasse & \multicolumn{3}{|c|}{$\bar{Y}=1.26$} & --- & --- \\
\hline Coconut bagasse & \multicolumn{3}{|c|}{$\hat{Y}=1.12+0.01464 X$} & 0.96 & 100.00 \\
\hline Organomais & \multicolumn{3}{|c|}{$\hat{Y}=1.1046+0.1578 X-0.001369 X^{2}$} & 0.99 & 57.63 \\
\hline
\end{tabular}

The means followed by the same letter in the column do not differ statistically from each other by the Tukey test at $5 \%$ probability $(\mathrm{P}<0.05)$. Xmax - Best dose for the highest value of the studied characteristic.

For the structural parameters of leaf length and width, the best results obtained point to cattle manure and Organomais, with the recommended dosage to the substitution of the commercial substrate around $60 \%$ for both variables. These results (Tables 3 and 4) may be associated with the supply of nitrogen by these alternative substrates to the plants.

There is a direct relationship between leaf length and width and leaf area index (LAI), and this with the photosynthetic activity of plants. Thus, it can be inferred that with a larger leaf area for light absorption, seedlings produced with $60 \%$ of alternative substrate (cattle manure or Organomais) and $40 \%$ of the commercial substrate Plantmax ${ }^{\circledR}$ accumulated more dry matter. This is due to the higher leaf area available to capture light and the possible increase in photosynthesis when compared to other treatments. It is verified that the addition of cattle manure and Organomais in the concentrations of $63 \%$ provided a significant increase in the number of leaves (Table 5). Also, for this variable, the use of $100 \%$ of equine manure and coconut bagasse had better results than the treatment that contained only the commercial substrate Plantmax ${ }^{\circledR}$.

The plant height is one of the characteristics used by the producer as an indication of the best moment to the seedling transplanting into the field. The use of tall seedlings, for example, improves the quality of passion fruit when compared to conventional seedling planting (Santos et al., 2017a). Besides, this management technique also helps in controlling the fruit-hardening virus (Bertani et al., 2019). The highest plant height values found in the present study were 20.18 and 17.30 $\mathrm{cm}$ for seedlings produced with about $60 \%$ cattle manure or Organomais, respectively, added to the commercial substrate. Santos et al. (2017a), evaluated the production of passion fruit seedlings with different reflective materials on the bench, and they found at 70 DAS averages plant height between 22 and $36 \mathrm{~cm}$. Considering the values of the present study represent the plant height in a shorter period, it can be inferred that, in general, the data are within the recommended for the production of yellow passion fruit seedlings. Thus, the producer must use alternative substrates that provide essential compounds for the best development of the plant. According to the present study, cattle manure and the Organomais compound are the most indicated.

Commercial substrates are more expensive and depend on availability for each region. It was found, in Table 6 , that to replace $100 \%$ of the commercial substrate with some alternative, coconut bagasse and equine manure were also efficient. Seedlings produced in these conditions reached about $3.5 \mathrm{~cm}$ height when compared to the exclusive use of the commercial substrate.

About the effect of cattle manure on the shoot dry matter of the passion fruit seedlings, an adjustment of the equation with the coefficient of determination of 0.95 is observed in Table 7, which indicates the equation is representative. The dose of cattle manure that provided the maximum growth of passion fruit seedlings was determined by matching the first derivative of the best-fit regression equation to zero. Thus, the highest plant height $(21.1 \mathrm{~cm})$ was found with $58.74 \%$ of cattle manure. For the Organomais compound, the addition of $55.57 \%$ in the commercial substrate promoted a plant height of 18.81 $\mathrm{cm}$. In the reality of the producer, it can be said that the addition of these two alternative substrates between 50$60 \%$ to the commercial substrate provides the highest plant height.

Even though it is one of the most used commercial substrates, Plantmax ${ }^{\circledR}$, individually, was not efficient in 
producing passion fruit seedlings. Unlike vegetables, passion fruit can be more demanding in terms of the chemical composition of the substrate. Because it takes longer to go to the field, it needs better levels of essential elements.

One of the factors for choosing the material that will make up the substrate is the availability of acquisition and transport. The producer can use elements of his own to formulate the best combination; knowing this and based on the results found, different types of manure are an alternative. The addition of poultry, equine, or cattle manure to the commercial substrate Plantmax ${ }^{\circledR}$ promoted higher values of shoot dry mass in yellow passion fruit seedlings when compared to those produced only with Plantmax ${ }^{\circledR}$ (Table 7).

Miyake et al. (2017) evaluated the production of yellow passion fruit seedlings, and they observed higher values of shoot dry matter when $600 \mathrm{mg} \mathrm{dm}^{-3}$ of nitrogen were applied to the Bioplant ${ }^{\circledR}$ and coconut fiber substrates. These authors found that the highest shoot dry matter was around $15.0 \mathrm{~g} \mathrm{plant}^{-1}$, at 120 days after sowing. In the present study, the highest value observed for this variable was 20.18 g plant $^{-1}$ (Table 7), when approximately $55 \%$ of cattle manure was used to compose the substrate.

Table 5. Number of leaves of yellow passion fruit seedlings under different concentrations of alternative substrates, Juazeiro-BA (2016).

\begin{tabular}{|c|c|c|c|c|c|}
\hline \multirow{2}{*}{ Alternative substrates } & \multicolumn{5}{|c|}{ Proportion of alternative substrate $(\%)$} \\
\hline & 0 & 25 & 50 & 75 & 100 \\
\hline & \multicolumn{5}{|c|}{ - } \\
\hline Poultry manure & $4.80 \mathrm{a}$ & $7.60 \mathrm{a}$ & $3.60 \mathrm{c}$ & $0,00 \mathrm{e}$ & $0,00 \mathrm{e}$ \\
\hline Equine manure & $4.00 \mathrm{a}$ & $4.80 \mathrm{~b}$ & $5.80 \mathrm{~b}$ & $6,00 \mathrm{~b}$ & $6,20 \mathrm{~b}$ \\
\hline Cattle manure & $4.00 \mathrm{a}$ & $9.20 \mathrm{a}$ & $9.00 \mathrm{a}$ & $9,20 \mathrm{a}$ & $8,40 \mathrm{a}$ \\
\hline Sugarcane bagasse & $4.60 \mathrm{a}$ & $4.00 \mathrm{bc}$ & $3.40 \mathrm{c}$ & $3,60 \mathrm{~cd}$ & $4,40 \mathrm{~cd}$ \\
\hline Coconut bagasse & $4.00 \mathrm{a}$ & $4.00 \mathrm{bc}$ & $4.20 \mathrm{bc}$ & $5,00 \mathrm{bc}$ & $5,20 \mathrm{bc}$ \\
\hline \multirow[t]{2}{*}{ Organomais } & $4.20 \mathrm{a}$ & $8.00 \mathrm{a}$ & $9.20 \mathrm{a}$ & $9,40 \mathrm{a}$ & $8,00 \mathrm{a}$ \\
\hline & \multicolumn{3}{|c|}{ Adjusted equations } & $\mathrm{R}^{2}$ & Xmax \\
\hline Poultry manure & \multicolumn{3}{|c|}{$\hat{Y}=5.8971-0.009371 X-0.0005943 X^{2}$} & 0.74 & 7.88 \\
\hline Equine manure & \multicolumn{3}{|c|}{$\hat{Y}=4.24+0.0224 X$} & 0.90 & 100.00 \\
\hline Cattle manure & \multicolumn{3}{|c|}{$\hat{Y}=4.5429+0.1678 X-0.001326 X^{2}$} & 0.87 & 63.28 \\
\hline Sugarcane bagasse & \multicolumn{3}{|c|}{$\bar{Y}=4.00$} & --- & --- \\
\hline Coconut bagasse & \multicolumn{3}{|c|}{$\hat{Y}=3.8+0.0136 X$} & 0.87 & 100.00 \\
\hline Organomais & \multicolumn{3}{|c|}{$\hat{Y}=4.3314+0.1663 X-0.001303 X^{2}$} & 0.99 & 63.82 \\
\hline
\end{tabular}

The means followed by the same letter in the column do not differ statistically from each other by the Tukey test at $5 \%$ probability $(\mathrm{P}<0.05)$.

Xmax - Best dose for the highest value of the studied characteristic.

Table 6. Plant height of yellow passion fruit seedlings under different concentrations of alternative substrates, Juazeiro-BA (2016).

\begin{tabular}{|c|c|c|c|c|c|}
\hline \multirow{2}{*}{ Alternative substrates } & \multicolumn{5}{|c|}{ Proportion of alternative substrate (\%) } \\
\hline & 0 & 25 & 50 & 75 & 100 \\
\hline & \multicolumn{5}{|c|}{ 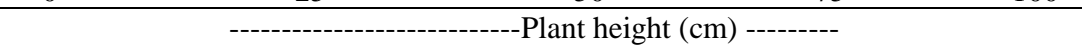 } \\
\hline Poultry manure & $5.30 \mathrm{a}$ & $15.00 \mathrm{~b}$ & $7.26 \mathrm{~b}$ & $0,00 \mathrm{~d}$ & $0,00 \mathrm{~d}$ \\
\hline Equine manure & $5.20 \mathrm{a}$ & $5.48 \mathrm{c}$ & $6.50 \mathrm{~b}$ & $8,06 \mathrm{~b}$ & $8,70 \mathrm{~b}$ \\
\hline Cattle manure & $4.90 \mathrm{a}$ & $19.06 \mathrm{a}$ & $20.18 \mathrm{a}$ & $18,40 \mathrm{a}$ & $14,68 \mathrm{a}$ \\
\hline Sugarcane bagasse & $4.70 \mathrm{a}$ & $5.14 \mathrm{c}$ & $4.96 \mathrm{~b}$ & $4,76 \mathrm{bc}$ & $4,64 \mathrm{c}$ \\
\hline Coconut bagasse & $5.00 \mathrm{a}$ & $6.20 \mathrm{c}$ & $6.78 \mathrm{~b}$ & $8,08 \mathrm{~b}$ & $8,74 \mathrm{~b}$ \\
\hline Organomais & $5.72 \mathrm{a}$ & $16.06 \mathrm{a}$ & $17.52 \mathrm{a}$ & $17,70 \mathrm{a}$ & $10,64 \mathrm{~b}$ \\
\hline & \multicolumn{3}{|c|}{ Adjusted equations } & $\mathrm{R}^{2}$ & Xmax \\
\hline Poultry manure & \multicolumn{3}{|c|}{$\hat{\mathrm{Y}}=7.9274+0.1139 \mathrm{X}-0.002163 \mathrm{X}^{2}$} & 0.59 & 26.33 \\
\hline Equine manure & \multicolumn{3}{|c|}{$\hat{Y}=4.872+0.03832 X$} & 0.96 & 100.00 \\
\hline Cattle manure & \multicolumn{3}{|c|}{$\hat{Y}=6.1411+0.254139 X-0.002163 X^{2}$} & 0.91 & 58.56 \\
\hline Sugarcane bagasse & \multicolumn{3}{|c|}{$\hat{\mathrm{Y}}=4.84$} & --- & --- \\
\hline Coconut bagasse & \multicolumn{3}{|c|}{$\hat{Y}=5.088+0.03744 X$} & 0.99 & 100.00 \\
\hline Organomais & \multicolumn{3}{|c|}{$\hat{Y}=6.0778+0.45826 X-0.004123 X^{2}$} & 0.97 & 55.57 \\
\hline
\end{tabular}

The means followed by the same letter in the column do not differ statistically from each other by the Tukey test at $5 \%$ probability $(\mathrm{P}<0.05)$. Xmax - Best dose for the highest value of the studied characteristic. 
Table 7. Shoot dry matter of yellow passion fruit seedlings under different concentrations of alternative substrates, Juazeiro-BA (2016).

\begin{tabular}{|c|c|c|c|c|c|}
\hline \multirow{2}{*}{ Alternative substrates } & \multicolumn{5}{|c|}{ Proportion of alternative substrate (\%) } \\
\hline & 0 & 25 & 50 & 75 & 100 \\
\hline & \multicolumn{5}{|c|}{---ory matter $\left(\right.$ g plant $\left.^{-1}\right)$------ } \\
\hline Poultry manure & $0.029 \mathrm{a}$ & $0.230 \mathrm{~b}$ & $7.26 \mathrm{~b}$ & $0,00 \mathrm{~d}$ & $0,00 \mathrm{~d}$ \\
\hline Equine manure & $0.031 \mathrm{a}$ & $0.020 \mathrm{c}$ & $6.50 \mathrm{~b}$ & $8,06 \mathrm{~b}$ & $8,70 \mathrm{~b}$ \\
\hline Cattle manure & $0.029 \mathrm{a}$ & $0.376 \mathrm{a}$ & $20.18 \mathrm{a}$ & $18,40 \mathrm{a}$ & $14,68 \mathrm{a}$ \\
\hline Sugarcane bagasse & $0.028 \mathrm{a}$ & $0.030 \mathrm{c}$ & $4.96 \mathrm{~b}$ & $4,76 \mathrm{bc}$ & $4,64 \mathrm{c}$ \\
\hline Coconut bagasse & $0.030 \mathrm{a}$ & $0.069 \mathrm{c}$ & $6.78 \mathrm{~b}$ & $8,08 \mathrm{~b}$ & $8,74 \mathrm{~b}$ \\
\hline \multirow[t]{2}{*}{ Organomais } & $0.029 \mathrm{a}$ & $0.226 \mathrm{~b}$ & $17.52 \mathrm{a}$ & $17,70 \mathrm{a}$ & $10,64 \mathrm{~b}$ \\
\hline & \multicolumn{3}{|c|}{ Adjusted equations } & $\mathrm{R}^{2}$ & Xmax \\
\hline Poultry manure & \multicolumn{3}{|c|}{$\hat{\mathrm{Y}}=0.0816-0.00188 \mathrm{X}-0.0000304 \mathrm{X}^{2}$} & 0.36 & 30.92 \\
\hline Equine manure & \multicolumn{3}{|c|}{$\bar{Y}=0.030$} & --- & --- \\
\hline Cattle manure & \multicolumn{3}{|c|}{$\hat{Y}=0.05531-0.01376 X-0.0001282 X^{2}$} & 0.95 & 53.65 \\
\hline Sugarcane bagasse & \multicolumn{3}{|c|}{$\bar{Y}=0.0196$} & --- & --- \\
\hline Coconut bagasse & \multicolumn{3}{|c|}{$\bar{Y}=0.049$} & --- & --- \\
\hline Organomais & \multicolumn{3}{|c|}{$\hat{Y}=0.05531-0.01376 X-0.0001282 X^{2}$} & 0.90 & 54.02 \\
\hline
\end{tabular}

The means followed by the same letter in the column do not differ statistically from each other by the Tukey test at $5 \%$ probability $(\mathrm{P}<0.05)$. Xmax - Best dose for the highest value of the studied characteristic.

Thus, the use of alternative substrates with chemical composition favorable to plant nutrition does not require the application of fertilizers on commercial substrates, when considering obtaining quality seedlings. Therefore, cattle manure can be used to increase the plant height, the number of leaves, and shoot dry matter of yellow passion fruit seedlings. Besides, it can also reduce production costs, as it can be obtained on the property and does not require the use of chemical fertilizers.

Animal manure, mainly cattle, as well as Organomais, has a high potential for use as a substrate. They are easy to handle and has low cost, especially for small and medium producers that have a diversified production chain, thus using animal waste and maximizing productivity.

\section{Conclusions}

The addition of $60 \%$ cattle manure or Organomais to the commercial substrate Plantmax ${ }^{\circledR}$ proved to be the best composition for the production of yellow passion fruit seedlings, as it has a higher length, width, and the number of leaves, plant height and shoot dry matter.

\section{Bibliographic References}

Agrianual 2018 - Anuário da Agricultura Brasileira, 2018. São Paulo, Informa Economics IEG/FNP, 456 p.

Aguiar, R.S., Zaccheo, P.V.C., Stenzel, N.M.C., Sera, T., Neves, C.S.V.J., 2015. Produção e qualidade de frutos híbridos de maracujazeiro-amarelo no Norte do Paraná. Revista Brasileira Fruticultura, 37(1), 130-137.

Bertani, R.M.A, Silva, S.P., Deus, A.C.F., Antunes, A.M., Fischer, I.H, 2019. Doses de nitrogênio no desenvolvimento de mudas altas de maracujá-amarelo. Journal of Neotropical Agriculture, 6(1), 29-35.
Brugnara, E.C., Nesi, C.N., Verona, L.A.F., 2014. Cama de aviário e composto de dejetos suínos em substratos para mudas de maracujazeiro-amarelo. Científica, 42(3), 242-251.

Costa, E., Santo, T.L.E., Silva, A.P., Silva, L.E., Oliveira, L.C., Benett, C.G.S., Benett, K.S.S., 2015. Ambientes e substratos na formação de mudas e produção de frutos de cultivares de tomate cereja. Horticultura Brasileira, 33(1), 110-118.

Lima, I.M.O, Júnior, J.S.S., Costa, E., Cardoso, E.D., Silva Binotti, F.F., Jorge, M.HA., 2016. Diferentes substratos e ambientes protegidos para o crescimento de mudas de maracujazeiro amarelo doce. Revista de Agricultura Neotropical, 3(4), 39-47.

Miyake, R.T.M, Creste, J.E, Narita, N., Guerra, X., Eduardo, W., 2017. Substrato e adubação nitrogenada na produção de mudas de maracujazeiro amarelo em condições protegidas. Colloquium Agrariae, 13(1), 57-65.

Oliveira, F.S., Farias, O.R., Nobre, R.G., Ferreira, I.B., Figueredo, L.C., Oliveira, F.S., 2015. Produção de mudas de mamoeiro 'Formosa' com diferentes doses de esterco ovino. Revista de Ciências Agrárias, 58(1), 52-57.

Oliveira, J.R., Xavier, F.B., Freitas Duarte, N., 2013. Húmus de minhoca associado a composto orgânico para a produção de mudas de tomate. Revista Agrogeoambiental, 5(2), 19-86.

Santos, T.V., Lopes, T.C., Silva, A.G., Paula, R.C.M., Costa, E., Binotti, F.F.S., 2017a. Produção de mudas de maracujá amarelo com diferentes materiais refletores sobre bancada. Revista de Agricultura Neotropical, 16(4), 26-32.

Santos, V.A., Ramos, J.D., Laredo, R.R., Silva, F.O.R., Chagas, E.A., Pasqual, M., 2017b. Produção e qualidade de frutos de maracujazeiro-amarelo provenientes do cultivo com mudas em diferentes idades. Revista de Ciências Agroveterinárias, 16(1), 33-40. 